\title{
Waterschappen (Irrigation Agencies) Management in Vorstenlanden Surakarta and Yogyakarta, 1900-1942
}

\author{
Machmoed Effendhie \\ Universitas Gadjah Mada \\ Email: efendhie@ugm.ac.id \\ Arif Rahman Bramantya \\ Graduate Student, Universitas Gadjah Mada \\ Email: arif_bramantya@yahoo.com
}

\begin{abstract}
The purpose of this study is to track the introduction of the irrigation agency (Watershappen) in the Vorstenlanden area Surakarta and Yogyakarta as well as effects on the relationship between farmers, farmers and plantation owners. In addition, this study aims to understand the patterns of institutional change and the water distribution system in the Vorstenlanden region and consequently on agriculture and plantation. State involvement in the problem of water distribution in the Vorstenlanden area causing a collision between a proportional system that has been done by the traditional farmers with absolute system applied state. As a result, irrigation conflicts arise between plantations because of the use of a watershed point for some plantations. Conflicts between plantations and farmers because of water scarcity due to the autonomy of the estate in the distribution of water to agricultural land and conflicts between farmers as water encroachment without the knowledge of other farmers.
\end{abstract}

Keywords: Watershappen, Vorstenlanden, proportional system, absolute system, conflicts

\section{INTRODUCTION}

Vorstenlanden is a king territory covering an area of Surakarta Sunanate (Kasunanan Surakarta), Duchy of Mangkunegaran (Kadipaten Mangkunegaran), Yogyakarta Sultanate (Kasultanan Yogyakarta), and Duchy of Pakualaman (Kadipaten Pakualaman). Institutions that take care of irrigation in the Vorstenlanden region is Waterschap Centraal Kantoor voor Vorstenlanden and it is under the Department van Verkeer en Waterstaat. Waterschap Centraal Kantoor voor Vorstenlanden, or better known Waterschappen, based in Yogyakarta. The Institute is a technical institution and supervision of irrigation in Surakarta and Yogyakarta. Structurally, Centraal
Waterschaap Kantoor voor Vorstenlanden is a unit of irrigation from the Office of Inspector of the Bureau of Technical Administration Surakarta and Yogyakarta (Technische Zeljbestuurdiensten in Vorstenlanden) that serves as a technical advisor services agencies in the autonomous governments in Surakarta and Yogyakarta (MVO Helsdingen, 1929: 93).

Waterschapp Dengkeng and Bengawan in Surakarta and Waterschapp Opak Progo in Yogyakarta, responsible for structuring technical and administrative irrigation. Waterschapp as legal entities are expected to act neutral in resolving conflicts of interest between onderneming owners and farmers. This research tries to trace 
the development of modern irrigation agency (Waterschappen) in the Vorstenlanden region Surakarta and Yogyakarta and consequences thereof. For a century, since the opening Vorstenlanden regions for plantation areas, the owners have enjoyed the right to use water resources for operational plantations purposes. Meanwhile, plantations and agricultural interests of the people who wear the same land for plantation crops and food crops, and also require the same water, has raised the issue of water distribution. That is because there is no application of the rules of fair and neutral irrigation for farmers, for the autonomous government and for plantations in the distribution of water for agricultural purposes (Rouffaer, 1921: 380).

The involvement of the state in matters of water distribution in the Vorstenlanden area have caused collision between a proportional system and absolute system. Proportional system have been long established by the traditional farmers based on the size of the area of land to be drained. Meanwhile, the absolute system applied state, the drainage of water on agricultural land are based on agronomic considerations such as the need for water on each plant. Absolute system have been based on the consideration of technical and agronomic standard, based on the condition of plants in an agricultural area. (Ravesteijn, 1998: 105.). At the turn of the 20th century began to change because of increased concern for the welfare of the indigenous population and the strong political influence of the sugar industry. Irrigation agencies converted into an independent organization with a technocratic ideology by linking irrigation with prosperity, progress, and civilization. Technocratic ideology is what eventually became a very important element in the policy of ethical politics.

Based on the above, the main issues that arises is why the modern irrigation once established institutions in the Vorstenlanden region it raises new issues of the institutional aspects and farmers relationships with farmers, farmer relations with plantation owners. The purpose of this study is to investigate the process of esta blishment of modern irrigation in the Vorstenla nden region and its consequences on relations between farmers, farmers and plantation ow ners, and the relationship between the owners of the plantation.
In addition, this study aims to un derstand the patterns of institutional change a nd the water distribution system in the Vorsten landen region and consequently on agriculture an d plantation sector. In order to answer the afo rementioned research questions, I will analyse information gathered from primary and secondary sources. This study mostly uses the primary source in the form of archives. Information from archival sources will be sought from official sources of the colonial government, especially reports stored at Library and regional archives in Yogyakarta, Pakualaman, and Mangkunegaran. Se condary sources are obtained from nationa 1 libraries in Jakarta and several libraries in Yogyakarta.

\section{ORGANIZATIONAL AND OPERATIONAL AREA WATERSCHAP CENTRAAL KANTOOR VOOR VORSTENLANDEN}

Waterschapp Centraal Kantoor voor Vorstenlanden founded in 1917. The operations area includes the Waterschapp Opak Progo (Yogyakarta), Waterschapp Dengkeng and Waterschapp Bengawan (Surakarta). Meanwhile, units of irrigation in the region of Yogyakarta (Bestuur van Het Waterschapp Opak-Progo) there is an Advisory Board (Raad van Waterschapp OpakProgo) whose members consist of several agencies, among others planter (Beheerder Onderneming), Assistant Resident, municipal inspectors (Controleur Binenlands Bestuur), Regent, Head of subdistrict (Wedana), and the Head Office of land affairs. Irrigation Unit in Surakarta (Waterschapp Dengkeng and Bengawan) contained Irrigation Council whose members include elements of the duke as a representative of the autonomous governments, official representative of the residents, and representatives from the company's plantations. (Article 10 Vorstenlandsche Waterschapp Ordonance (VWO) in NI Gazette, No. 722,1922 ).

For the technical implementation is done by the Technical Office (Technische Dienst). The Technical Service employee is employed Waterschapp Centraal Kantoor personnel from the Technical Office. Meanwhile, under Tecnische Dienst there Technische Amtenaren which is the technical officers consisting of two natives. Under the Technische Amtenaren there are three sections: 
South Section (Sectie Zuid), West Section (Sectie West), and Eastern Section (Sectie Oost). Sections supervised some onderneming. Head section is held by indigenous and assisted in their duties by Irrigation Foreman (Mandor Water Beheer). Irrigation Foreman appointed by Bestuur van het Waterschapp-Opak Progo and given a salary and salary increases each year over the proposed Section Head with the approval of Chief Technical Office. Irrigation Foremen assisted in their duties by some employees maid (Hulppersoneel) consisting Staff foreman (Hulpmandoer), Doorman water (Sluiwachter), Guard Dam (Damwachter), and Guard Sijphon (Sjiphonwaker). In addition there is also a Mantri Oeloe-Oeloe (Archive Waterschapp Opak-Progo 1929-1942, Collection number 2228 / H Bd. 1170).

By hierarchical, Waterschappen based on the unity of irrigation sections and in afdeeling level headed by an engineer. Section chief in charge of irrigation orderlies (mantri) and under irrigation orderly contained foreman (mandor) positions. Section chief duties include organizing and planning the technical aspects such as damming permanently. The task of irrigation orderly conduct supervision of foreman. Foreman and foreman assistant in charge of overseeing the irrigation channel. Foreman assistant is the lowest echelon in irrigation agencies. Across the regions Surakarta and Yogyakarta, the number of orderlies personnel about 50 people and the amount of irrigation foreman 300 (Joon, 1940: 5).

Technical and administrative arrangement of irrigation has been conducted in Waterschapp Dengkeng and Bengawan (Surakarta) and Waterschapp Opak Progo (Yogyakarta). All matters relating to the operation and maintenance of irrigation facilities, are handled by a semiautonomous agency. The legal consequences of the establishment of semi-autonomous agency of irrigation is the revocation of the right to development and exploitation of irrigation facilities previously held by plantation owners (Joon, 1940: 2). Some of the irrigation department in the autonomous region Vorstenlanden melted. In Mangkunegaran, for example, in 1926 the irrigation department Karanganyar merged into Waterschapp Bengawan. Section of Sragen region

Figure 1

Organizational Structure Institute of irrigation in Vorstenlanden

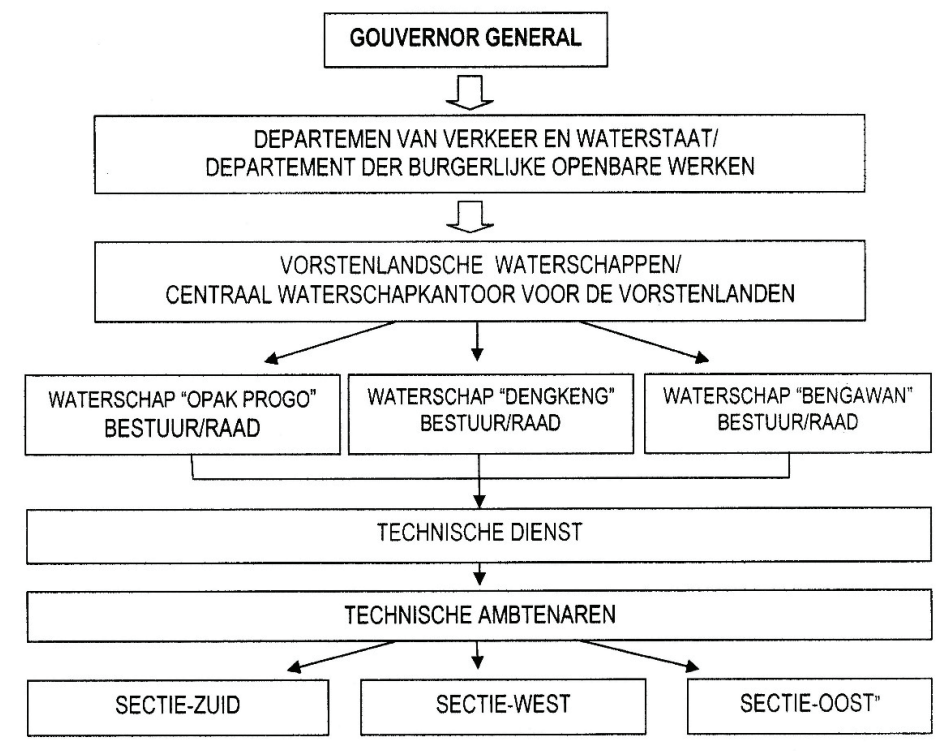

Sources: Inventaris Arsip Vorstenlandensche Waterschappen, p. 16. 
network operation (section of Karanganyar) and Solo (section of Colomadu) previously included Kring Pepe irrigation merged into the operating area of Waterschapp Bengawan (Angenent, 1933: 34).

Operational area of Waterschapp Opak Progo covers an area measuring 64,200 bau that includes 25 estates, mostly located in the Region of Yogyakarta. Scope of exploitation is Afdeeling of Yogyakarta, Kulon Progo and Afdeeling of Klaten in Surakarta. Borders of Waterschapp Opak Progo region covering northern regions, ranging from the Krasak river that disgorge at Merapi mountains until the estuary of Opak river in the Indian Ocean. On the Eastern border is the Opak river, in the southern part includes the Progo river, Krasak, and Serang. Meanwhile, the scope of work Waterschapp Dengkeng covering 64,200 bau, includes 27 estates. Scope exploitation of the northern regions, ranging from the mountains of Merapi, Kadipiro River basin and Pusur river, Brambang river, until the border Afdeeling of Klaten and Boyolali. The southern border areas ranging from Nglumbe river basin in Baderan to Brambang river. In the eastern area ranging from Bengawan river basin, Dengkeng, to the south of the border between the residency of Surakarta and Yogyakarta. While the western border up in the catchment Opak area (Angenent, 1933: 15).

Scope of work area Waterschapp Bengawan measuring 68,000 bau, including the two onderneming. Coverage of exploitation in the north began bordering near the village of Pepe river in Nganti, the border river flow Cemoro up towards the Bengawan Solo. In the eastern part until the Sawur river tipped over Lawu mountain peaks. In the southern part of the border streams start Jlantah river until bridge near Tlobo village until to Jatipuro. At the Eastern start of Baboon river (area Jatipuro) Bengawan river, the Gandul river, the border area south of the river flow Nglumbi in Baderan, until the border Afdeeling of Klaten and Boyolali. In the west to the border of the western part of the Pepe river flow.
Figure 2

Operational areas of irrigation Institutions in Vorstenlanden

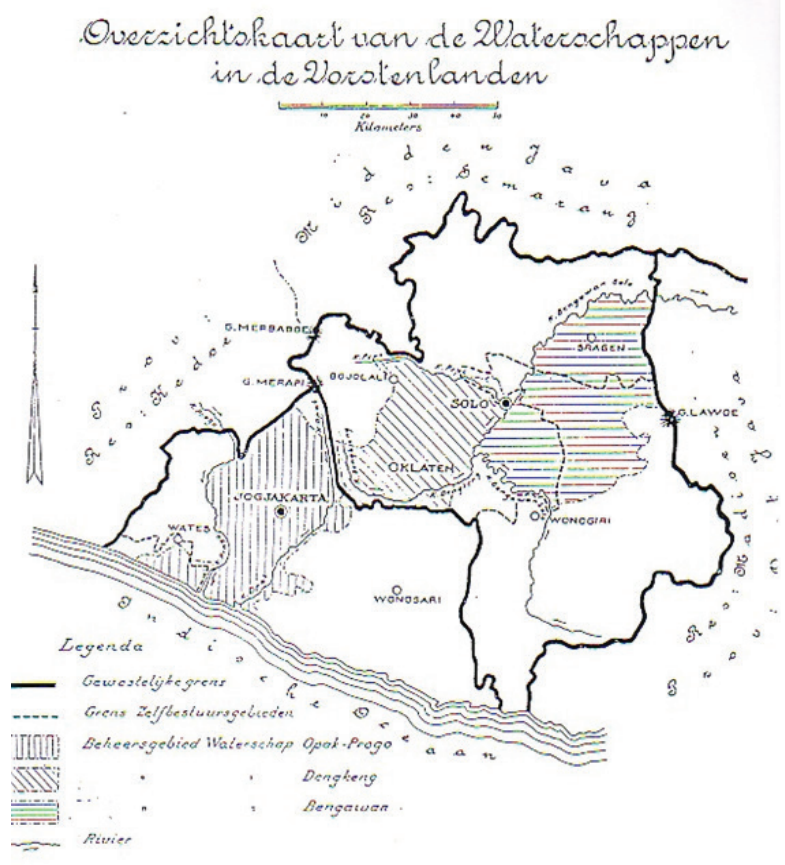

Sources: Angenent, 1933.

\section{DEVELOPMENT OF MODERN IRRIGATION AND INTERESTS OF PLANTATION INDUSTRIES}

The development of irrigation semi-modern facilities in the Vorstenlanden had started almost simultaneously with the development of plantation sector. Private planters in Surakarta, for example, has allocated millions of guilders for the construction of irrigation facilities to support the operation and expansion of the plantation sector in Surakarta. (Joon, 1940: 4.) The criteria for selection was based on the availability of land for plantations adequate water supply and the possibility of increasing the area of land to be planted. Once that is done the construction of dams and water channels before starting the cultivation of the soil (Houben, 1994: 293). Meanwh i le, until the year 1910, growers in Yogyakar ta has built several irrigation facilities, which are then integrated into the modern irrigation sy stem. 
Figure 3

Means of onderneming Irrigation until 1910

\begin{tabular}{|c|l|l|l|}
\hline No & Onderneming & Building Type & $\begin{array}{c}\text { Building } \\
\text { Name }\end{array}$ \\
\hline 1 & $\begin{array}{l}\text { Medari } \\
\text { aqueduct }\end{array}$ & $\begin{array}{l}\text { Aqueducts } \\
\text { Channel }\end{array}$ & Sempoe II \\
\hline 2 & Sendang Pitoe & $\begin{array}{l}\text { Large } \\
\text { Irrigation } \\
\text { Channels }\end{array}$ & $\begin{array}{l}\text { Channels } \\
\text { Van der Wijk }\end{array}$ \\
\hline 3 & Padokan & $\begin{array}{l}\text { Dam } \\
\text { Permanent }\end{array}$ & $\begin{array}{l}\text { Pam } \\
\text { Permanent } \\
\text { Tandjong }\end{array}$ \\
\hline 4 & Randoegunting & Dam & $\begin{array}{l}\text { Dam } \\
\text { Kringinan }\end{array}$ \\
\hline 5 & Medari & Dam & $\begin{array}{l}\text { Dam Kali } \\
\text { Bedok }\end{array}$ \\
\hline
\end{tabular}

Sources: Adapted from J.J Tichelaar, De Java Suikerindustrie en hare beteekenis voor Land en Volk (Published by the Joint Syndicate of Sugar Factory Nederland Indie, nd), p. 9, 23, and 31.

In 1920 was constructed Larangan irrigation channels in Mangkunegaran. With the completion of the construction of irrigation facilities is very useful to prevent flooding of villages in the surrounding villages (MVO J. van der Marel, 1924: 78). In 1921 the dam was built in Jlantah river in Jombor, Afdeeling of Klaten and in 1922 built a dam in Bajran to spend f 67,000. In 1922 began the construction of Delingan reservoirs in Tirtomarto and execution completed in September 1922. The reservoir is very useful for irrigation facilities around the Tasikmadu Sugar Factory in Afdeeling of Karanganyar. The funds needed for the construction of the entire reservoir totaled $\mathrm{f}$. 614,000 . A quarter of the funds contributed by Mangkunegaran palace and 3/4 of contributions Tasikmadu Sugar Factory. Delingan reservoir in the form of a large water reservoir or reservoir by damming the upstream Jirak river. The dam is the extent of 500,000 cubic meters and contains $4,000,000$ cubic meters of water discharge. With the construction of the irrigation water shortage can be overcome (A.K. Pringgodigdo, 1950: 196). With the Delingan construction of reservoirs, water supply in the dry and rainy season from the area around the reservoir can be increased by
12,000 bau (MVO J. van der Marel, 1924: 79) and 8515 ha of sugarcane area in Tasikmadu can be fed throughout the year.

In 1923 completed the construction of the main channel in the city of Solo, which cost up to $f 86$ 237 which partly contributed by Mangkunegaran amount 29387 Gulden (MVO van der Marel, 1924: 80). In 1924 began a program launched by the improvement of irrigation facilities in the Jetu area in Afdeeling of Karanganyar. The program aims to improve conditions for agricultural irrigation in the area, especially around the area of Tasikmadu sugarcane. The program in the improvement of receiver channel, floodgates, and the means of draining the main divider 1000 bau, help s supply and distribution in the region and surrounding territories Trani in Triagan Afdeeling of Karanganyar (MVO van der Marel, 1924: 80). The improvement of irrigation facilities spent of f 60,000 most of which are owned plantations and contributing Mangkunegaran Palace. In 1924 built irrigation facilities in Sugihan river, Wiroko river basin, in Afdeeling of Wonogiri with funds f 60,000 . Irrigation facilities is a means of prime divi s ors of aqueducts Sugihan river. In 1926 buil $t$ another irrigation facilities in Kalongan, Kara nganyar, which is part of the general plan for the improvement of irrigation reservoir in Delingan. This development such as construction of $\mathrm{K}$ a longan kanal along the 3000 meter, 5000 mete $\mathrm{r}$ long secondary channel in Jogopaten, as well as the improvement of means of increasing water discharge from Singit river. In April 1926 completed the construction of Jombor reservoirs in Klaten. This reservoir is needed because the population in the Jombor area at the dry season is a 1 ways a shortage of water, especially for agric ulture (MVO van der Marel, 1924: 81).

In 1927 the dam was completed in Ngancar Baturetno. This reservoir has an intake capacity of $1,500,000$ cubic meters and managed to irrig ate the rice paddies of 4000 bau. The total construction cost of $f 150,000$ of which were borne by Mangkunegaran. In 1927 also resolved tapper chan $\mathrm{n}$ el reservoirs Batal in Wiroko Afdeeling of W o nogiri. Construction of irrigation system for i rrigating the area 400 bau and spend $\mathrm{f}$. 250, 0 00. (Rijksblaad Mangkunegaran 1927: 3540). For the purposes of plantation expansion 
project in the north Klodran of the Pepe river built also Cengklik reservoir at a cost of f. 637,000. Cons t ruction of irrigation facilities is intended to s u pply water to the expansion of the plant and increase the milling capacity PG Tasikmadu (Rijksblaad Mangkunegaran 1927: 45-46) In 1927 also resolved tapper channel reservoirs in Wiroko Afdeeling of Wonogiri. Construction of irrigation system for irrigating the area 400 bau that spent f 250,000. (Rijksblaad Mangkunegaran 1927: 35 40.)

Implementation of Nederlansche Waterschapp Vorstenlanden Ordonantie in fact the same as the implementation of the principle of law for the lease of 1 and (Vorstenlandsche Grondhuurreglement). Both set of legal certainty for European plantation acti v ity. Aspects of soil and water as one comp o nent of the production process aimed at integrating plantation soils were scattered and cut pieces into a vast estate. The formation of a block plantations, easy management from the standpoint of $m$ a nagement, irrigation, transport, lay of the land and reduce the cost of labor exploitation (Suh a rtono, 1992: 97). According to reports Helsdingen's resident, in 1929 has been converted appanages area of 93240 bau throughout Surakarta (MVO Helsdingen, 1929: 68). Another factor that supports the centralized location of the estate is the impact of agrarian reorganization. In the opinion of the Nieuwenhuijs's resident linkages between land reorganization and reorganization of the irrigation sector is a cornerstone of the implementation of comp r ehensive land $r$ eorganization program in the Vorstenlanden region (MvO Nieuiwenhuijs., Memor i Serah Terima Jabatan Jawa Timur dan Tana h Kerajaan, Jak a rta: ANRI, 1978, hlm. cclxii.).

With the establishment of Waterschapp Opak Progo, Dengkeng and Bengawan, the role of the civil bureaucracy and the plantation owners in manag ing the distribution of water began to be reduced. It was due to the strengthening of the role and authority of the engineer in making the supply and distribution of water in the area of plantations in Vorstenlanden (Ravesteijn, 1998: 105). On the other hand, with the strengthening of the authority of the engineer in the control of the water supply is also accompanied by reduced government authority of the autonomous Yogyakarta Sultanate, duchy of Pakualaman, Surakarta Sunanate and duchy of Mangkunegaran. Irrigation bureaucratic apparatus in $\mathrm{S}$ i ndumarto, Mangkunegaran, for example, the number of personnel being phased including oper a tional funds. After 1933 Mangkunegara n irrigation department merged with the Department of $\mathrm{P} \mathrm{u}$ blic Works of Mangkunegaran. Previous inst $i$ tutions melting process begins with the inte gration of the operating area in Sindu merto, Kring Waterschapp Bengawan in 1927 (MVO Hels dingen, 1929: 102).

\section{PROBLEMS OF IRRIGATION: GROWERS AND FARMERS}

Auto n omous right of Onderneming to manage the $d$ evelopment and exploitation of irrigation facilities reserved leasing the land (Article $12 \mathrm{~b}$ Vors $t$ enlanden Grondhuureglement, Staatblad Nederlands Indie no. 20, 1918). The plantation company as a tenant has the right to determine the distribution of water for agriculture, industry, and $t$ he need others. As the excesses of the nature of an autonomous and privileges owned plan tation companies and the absence of legal auth ority owned autonomous government in the regulation and management of the problem of irrigation, often leads to the issue of dividing the allocation of water among the entrepreneurs. One of the consequences of the problem is the conflict division and the use of a watershed in Klaten in 1919 by the three estates in Gedaren, Ngupit and Keta $\mathrm{n}$ dan. The occurrence of misappropriation of implementation of irrigation systems day and night also accomplished by plantation companies. The manipulation is done by flowing water into the plantation areas during the day and night by tapping the river. The actions of these plantations caus e dissatisfaction among the population (Ritveld, 1927: 6).

The same thing also happened in Yogyakarta. Distribution Policy of water day and night which was i mplemented in 1841 , continues to be applied when the institution was founded modern irrigation. Regulation of water sharing thoroughly and u niformly throughout Dutch East Indies is not i mplemented by the colonial government in the Yogyakarta area. This issue submitted for each area or region with an agreement between onderneming and local farmers. During the day, 
water flowed in sugar cane crops and crop farmers in the dry state. At night, the water diverted from plantation crops to farmers' crops. In practice this system of day and night, it onderneming a lot of cheating. Often at night crop farmers who should get a share of the water but the water remained deta ined by onderneming. It is then often lead to theft of a water allocation and dispute among farmers to get water (Selosoemardjan, 1991: 226 227).

The occurrence of water shortages in the dry season is actually a natural thing, given the scarcity of water resources is a natural phenomenon that cannot be avoided. Water scarcity can be seen as a lack of quantity of natural resources but also as $1 \mathrm{i}$ mited access to water itself (Downing and Gibson, 1974: X). However, as a result of limited access and differences in water requirements for growers and farmers that finally lead to a conflict of interest between farmers and plantations. In some cases, conflicts are caused by lack of water supply due to the dry season occurs between farmers with estates. In the dry season, especially in May and Nove mber, the water supply is divided between watering to plant sugarcane and pulses (Deventer, 1914: 205.) Rotation planting sugarcane, pulses and rice lasts almost all year round. Sugar cane crop was planted in early April that the next dry seas on water allocation prioritized for breeding seed cane. Often the day and night watering rules are $\mathrm{n}$ ot complied with by the grower (Rapport van S uikeir Enqquete, 1928: 28). Farmers along the stream of Opak Progo, for example, in 1937 protests on the estates because a large part of the rive $r$ water used to fill the tanks of immersion Ross e la growers (Archive of Vorstenlandsche Water schappen, BPAD DIY, inventory number: 43-46)

In the region of Vorstenlanden, from June to September, farmers grow crops such as beans and soy. In these months if there are farmers who grow Gadu rice in areas that should be planted with crops, the Irrigation Department will regard as crops plant and irrigation quota equal to crops as many as $11 / 2$ parts water. In the rainy season, farmers will plant Dalem rice, 5-6 months old who usually start planting in January. Meanwhile, in the region of Waterschapp Opak Progo applied the rule that in the area of technical irrigation, the dry season cultivation Gadu rice only allowed in certain areas. In connection with these regulations, the Head of Waterschaap kantoor voor Centraal Vors t enlanden, Ir. Numans, exp l ained that the natives are not forbidden to $\mathrm{plant}$ Gadu rice in tech $\mathrm{n}$ ical irrigated (sawah ile $n$ an) in the dry season, but farmers are still planting rice must be prepared to accept the risk of water shortages, and will lead to crop failure. (Supomo, 1927: 88 89).

Irrig ation conflict between the plantation which happened in Klaten in 1919 for having used one point watershed in Dengkeng by three estates in Gedaren, Ngupit and Ketand an. The conflict arises because the plantation owners did not reach agreement on a neutral point of water delivery. The conflict is also fueled by the autonomous nature of the estate to the ownership of water resources. As a result of the conflict, the three onderneming is continuing with the closure of access roads to plan tations by their respec t ive owners (Joon, 1940 : 5). Irrigation confli $\mathrm{c} t$ between farmers and plantation companies a $\mathrm{r}$ e also common, espe cially in the area of sugarcane plantations. Water manipulation practices done by sugarcane plantations have been detrimental to farmers and result in dissatisfaction among farmers (Rietveld, 1927: 4). Conflict between growers and farmers often arise because farmers do theft of water by making a hole in the trench ditch water distribution (MVO van Wijck, 1914: 77). On 10 March 1937, in the village of Kedungpring, afdeeling Kulon Prog o, had been conflicts between farmers and farm ers as a matter of water dues (Pakualaman Archives, code 014.5.1.2.3667).

\section{CONCLUSIONS}

With the establishment of Waterschapp then applied the principle of centralized management and irrigation institutions. Irrigation plantation, Sult anate, Pakualaman, Mangkunegaran, Kasu nanan and the agricultural community, inte grated into a technical body. Legally, the lega 1 consequences of the establishment of mode $\mathrm{rn}$ irrigation agency is revocation of the righ $t$ to autonomy onderneming in irrigation mana gement in their own areas. But in reality, onde rneming retains the right of autonomous wate $r$ management with take cover behind the Hire Act land in Vorstenlanden (Vorstenlanden 
Gron dhuureglement).

Stat e involvement in irrigation in Vors tenlanden, through modern irrigation agencies, led to the collision of the proportional system which have been long established by the trad itional farmers with absolute system which appl ied state. As a result, conflicts of interest aris e between farmers and growers, farmers and plantation, plantation and the plantation. Irrigation conflict between plantation to appear because of the use of the watershed point for some plantations. The conflict arises because the plantation owners did not reach agreement on a neutral point of water delivery. The conflict is also fueled by the autonomous nature of the estate to the ownership of water resources is still maintained by the plantation.

Conflicts between farmers and the farmers also occur, especially in the area of sugarcane plantations. water manipulation practice performed by a sugar cane plantation has hurt many farmers and consequently appears discontent among farmers. In the conflict between growers and farmers often occur because farmers stealing water. Scarcity of water during the dry season also sparked conflict among farmers, especially in the area of sugarcane plantations. The conflict occurs because the seizure of water by farmers who turn makes aqueduct itself without being noticed by other farmers.

\section{REFERENCES}

Arsip Vorstenlandsche Waterschappen (2013). BPAD DIY, No, Inventaris 43-46.

Arsip Waterschap Opak-Progo Gubernemen Jogjakarta 1929-1942, Koleksi Kantor Arsip Propinsi DIY, No. 2228/H Bd. 1170

Assainerringswerken (1937). Arsip Pakualaman Code 014.51.2.3667.

Pringgodigdo, A.K (1950). Geschiedenis $d \quad e \quad r$ Onderneming van het Mangkunegorosche Rijks. s'Gravenhage: Martinus Nijhoff.

Angenent, P.H. (1933). De Vorstenlandche Waterschapp Ordonantie Toegelicht. GroningenBatavia: P. Noordhoff N.V.

Bijblad op het Staatblad van Nederlansch-Indie (1936). Batavia: Landrukerij.

Boomgard, Peter (ed.) (2007). A World of Water: Rain, Rivers and Seas in Southest Asian Histories.
Leiden: KITLV.

Effendi Pasndaran (2010) "Historical Perspective of Irrigation Management in Indonesia toward a New Wave of Development", Paper Presented at ICID - CIID Seminar on "History of Irrigation in Eastern Asia" 13 October, Yogyakarta, Indonesia

Ersten, Mourits (2006). "Aspects of Irrigation DevelopmentintheNetherlandEastindies",

The Journal for Transdisciplinary Research in Southern Africa, vol. 2., no. 1.

-, (2010). Locales of Happiness: Colonial Irrigation in the Netherlands East Indies and it is Remains, 1830-1980. Amsterdam: VSSD.

Houben, Vincent C. (1994). Kraton and Kumpeni, Surakarta and Yogyakarta 1830 - 1870, Leiden:KITLV Press.

Joon, P.L.E. (1940). "Eenige Bijzonderheden aangande Vorstenlandsche Watershappen", De Ingenieur in Nederlandsch Indie, no. 7e January

Kop Jan, at al. (2015). Irrigation Revisited: An Anthology ofIndonesia-Dutch Cooperation.

Delft: Eburon.

Memori Serah Terima Jabatan Jawa Timur dan Tanah Kerajaan. Nieuwenhuys G. V. Surakarta 15 Mei 1927 (Jakarta:ANRI,1978)

Memorie van Overgave van Wijck Resident Soerakarta van 4 April 1914. film 7 Koleksi Arsip Nasional Indonesia Jakarta.

Muhlenfeld, Monografi van Onderafdeeling Wonogiri (Surakarta: Koleksi Perpustakaan Rekso Pustoko Mangkunegaran) no.863,

MvO J.J. van Helsdingen, G. V Soerakarta van 10 Oktober 1929. Yogyakarta: koleksi Perpustakaan Kantor Gubenur DIY

MvO Treur, G. V Soerakarta van 26 Januari 1937. film 8, Jakarta: ANRI, 1937.

MvO J.J van der Marel Resident Soerakarta van 13 Maret 1924. film 7, Jakarta: ANRI 1924.

Metzelaar, J. Th. (1948). "Irrigatie", dalam C.J.J. van Hall en C. van de Koppel, De Landbouw in de Indische Archipel. Ia. 's-Gravenhage: N.V. Uitgeverij

Rapport van Suikeir Enqquete (1928). Surabaya: Soerabajasche Handelsblad.

Ravesteijn, Wim., 1998 . "Irigasi dan Negara Kolonial 18321940" Visi Irigasi Indonesia, no. 14 March. 
(2002). "Dutch Engineering overseas: The Creation of Modern Irrigation System in Colonial Java", Knowledge, Technology\&Policy, vol. 14.

Rijksblad Soerakarta 1917 N0. 39 (Yogyakarta: Koleksi Perpustakaan Kantor Gubenur DIY, 1917)

Rijksblaad Mangkunegaran 1927, (Yogyakarta: Koleksi Perpustakaan Kantor Gubemur DIY,1927)

Rietveld, J. Th. (1927). "De Inwengide Organisatie van de Vorstenlandsche Waterschappen", De Waterstaat Ingenieur no.7.

Rouffaer, (1921). Adatrechtbundell XIX Java en Madoera, seri D ('sGravenhage: Martinus Nijhoff.
Soemardjan, Selo (1991). Perubahan Sosial di Yogyakarta. Yogyakarta: Gadjah Mada University Press.

Staatblad NI, no 722 tahun 1922

Staatsblad 1918 no.469

Suhartono (1992). Apanage dan Bekel, Perubahan Sosial di Pedesaan Surakarta 18301920 , Yogyakarta: TiaraWacana.

Soepomo.(1927). De Reorganisatie van het Agrarische Stelsel in Het Gewest Surakarta, s'Gravenhage: L.Gerretzen. 